\title{
PENGARUH AROMATERAPI INHALASI TERHADAP PENURUNAN NILAI KECEMASAN PASIEN GAGAL GINJAL KRONIK YANG MENJALANI HEMODIALISA
}

\author{
TAHAN ADRIANUS MANALU \\ INSTITUT KESEHATAN MEDISTRA LUBUK PAKAM \\ JALAN SUDIRMAN NOMOR 38 LUBUK PAKAM \\ e-mail : tah aman@yahoo.co.id
}

DOI: https://doi.org/10.35451/jkf.v1i2.149

\begin{abstract}
Aromatherapy inhalation was complemantary therapy that most effective and safe to used, the physicology problem was anxiety as the impact of chronic kidney deasese who underwent hemodialysis. The purpose of this research was to know the influence of aromatherapy inhalation on the decreased anxiety value of chronic kidney deasese who underwent hemodialysis at Grendmed Hospital Lubuk Pakam 2018. This research was quantitative research, with research design pra-experiment and used approach one group pretest-posttest. This research population of all the patient chronic kidney deasese who underwent hemodialysis at Grandmed Hospital Lubuk Pakam 2018. Sample as many 13 respodences with tecnique used purposive sampling. Statistic test used paired simple t-test with confidence level $95 \%$ ( $a$ $=0,05)$. The result of the research that there was influence of aromatherapy inhalation on the decreased anxiety value of chronic kidney deasese who underwent hemodialysis at Grandmed Hospital Lubuk Pakam 2018 with p value $=0,001$. It is expected to the nurse to be able to apply the implamention the influence of aromatherapy inhalation on the decreased anxiety value of chronic kidney deasese who underwent hemodialysis to decrease dependency in farmacology therapy in decreasing anxiety.
\end{abstract}

Keywords : Aromatherapy inhalation, anxiety value

\section{PENDAhUlUAN}

Penyakit ginjal kronis (chronic kidney disease) bersifat irreversible atau tidak dapat kembali ke keadaan yang baik atau dipulihkan dan mengakibatkan keadaan penurunan progresif jaringan fungsi ginjal. Pada saat massa ginjal yang tersisa tidak dapat lagi menjaga lingkungan internal tubuh, maka akibatnya adalah gagal ginjal. Penyakit ini disebut CKD stadium 5 dan juga disebut penyakit ginjal stadium akhir End Stage Renal Disease (ESRD) (Wibowo, 2014).

Intervensi medis yang dapat dilaksanakan pada pasien dengan penyakit gagal ginjal kronis adalah dengan melaksanakan terapi/tindakan hemodialisis/ cuci darah tergantung pada keluhan pasien dengan keadaan kormobid dan parameter, kecuali apabila telah tersedia ada donor hidup yang sesuai yang ditentukan, 
keharusan akan tindakan suatu transplantasi terhambat oleh karena langkanya pendonor. Pilihan terapi dialisis meliputi hemodialisis (cuci darah) dan Peritoneal Dialisis (PD) (Widyono, 2015).

Dalam hal ini pasien juga mengalami ansietas yang dikarenakan terapi hemodilisa yang dijalani sepanjang hidupnya. Dalam penjadwalan dialisis dapat menciptakan kesulitan-kesulitan tersendiri. Konsep diri dan gambaran (citra) tubuh pasien mungkin berubah, mengakibatkan masalah-masalah pasien lebih jauh (Wibowo, 2014).

Kecemasan dapat didefinisikan sebagai suatu respon yang lama atau berkepanjangan terhadap adanya ancaman yang tak terduga, respon yang meliputi fisiologis, afektif, dan perubahan kognitif. Sejalan dengan aspek emosional dari gangguan kecemasan, pasien kecemasan akan mengalami suatu kesulitan untuk berkonsentrasi dan merasakan adanya perasaan terganggu yang berdampak negatif terhadap pekerjaan dan hubungan dengan orang lain (interpersonal) mereka. Dokter dan perawat yang bertugas di unit Hemodialisa telah berkolaborasisupaya dapat mengurangi kecemasan penderita GGK yang menjalani HD dengan cara pemberian obat anti cemas (anxiolytic). Hasil yang diperoleh dari pemberian obat tersebut cukup membantu pasien, akan tetapi petugas kesehatan juga cukup mengkhawatirkan efek samping yang ditimbulkan oleh obat anticemas. Berkenaan dengan hal tersebut, diperlukan sebuah terapi non farmakologis yang dapat membantu terjadinya penurunan tingkat kecemasan pasien GGK yang menjalani HD.
Hasil survei yang dilakukan pada saat studi pendahuluan di RS. Grandmed Lubuk Pakam, dari 24 pasien yang melaksanakan cuci darah (hemodialisa) terdapat 18 pasien yang mengalami kecemasan, 12 pasien yang baru menjalani terapi hemodialisa dan 6 pasien yang sudah berbulan-bulan menjalani terapi hemodialisa. Kecemasan terjadi karena pasien harus menjalani terapi dialisis 2-3 kali dalam seminggu dapat mengganggu pekerjaan, penurunan berat badan, gangguan citra tubuh karena kulit kering dan akan menghitam dan komplikasi intradialisis pada saat menjalani hemodialisa melainkan tekanan darah meningkat, mual muntah, kram otot.

Saat ini, Complementary and Alternative Medicine (CAM) sudah mulai digunakan dan dikembangkan dalam dunia kesehatan. Penggunaan CAM dalam dunia kesehatan diharapkan dapat menjadi pelengkap dari perawatan medis dan dapat diaplikasikan oleh tenaga kesehatan, khusunya tenaga dibidang keperawatan (Witarsa 2014). Salah satu jenis terapi CAM yang sedang popular digunakan dalam bidang kesehatan yaitu aromaterapi.

Saat Dalam penggunaannya, aromaterapi dapat diberikan melalui beberapa cara, antara lain inhalasi, berendam, pijat dan kompres (Witarsa, 2014). Dari keempat cara tersebut, cara yang tertua, termudah, dan tercepat diaplikasikan adalah aromaterapi inhalasi. Mekanisme kerja perawatan aromaterapi dalam tubuh manusia berlangsung melalui dua system fisiologis, yaitu sirkulasi tubuh dan sistem penciuman. Wewangian dapat mempengaruhi kondisi psikis, daya ingat, dan emosi seseorang (Widiyono, 2015). 
Senyawa aromaterapi melalui inhalasi akan langsung memberikan efek terhadap sistem saraf pusat dan mempengaruhi kesetimbangan korteks serebri serta saraf-saraf yang terdapat pada otak. Fragrance yang diberikan secara inhalasi akan merangsang system saraf olfactory yang dikendalikan oleh sistem saraf pada manusia, sehingga sistem saraf memberikan perintah kepada struktur otak untuk meresponnya. Saat senyawa aroma dihirup, senyawa tersebut dengan cepat berinteraksi dengan sistem saraf pusat dan langsung merangsang saraf pada system olfactory, kemudian sistem ini akan menstimulasi saraf-saraf pada otak di bawah kesetimbangan korteks serebral kemudian senyawa ini bekerja pada metabolisme monoamine dengan cara memblokade enzim monoaminooksidase dan meningkatkan konsentrasi monoamine di sistem saraf pusat. Mekanisme lainnya adalah penghambatan pada pengambilan kembali serotonin yang akan memperbaiki mood (Moelyono, 2015).

Data dari National Kidney and Urologic Disease Information Clearinghouse (NKUDIC) pada akhir tahun 2009, prevalensi penderita penyakit gagal ginjal stadium akhir di Amerika Serikat yaitu 1.738 penderita per satu juta penduduk dan 370.274 orang diantaranya menjalani hemodialisa (Rustina, 2012).

Data yang didapatkan pada tahun 2014 pada Program Indonesian Renal Registry (IRR) sebanyak 28.882 pasien hemodialisa diantaranya pasien baru yang menjalani hemodialisa sebanyak 17.193 dan yang aktif sebanyak 11.689 data yang disebutkan telah terlihat jumlah peningkatan pada pasien hemodialisa (IRR, 2014).

Berdasarkan data pasien hemodialisa untuk wilayah Sumatera
Utara sebanyak 957 pasien diantaranya pasien baru yang menjalani hemodialisa berjumlah 628 dan yang aktif sebanyak 329. Dalam hal ini pasien yang menjalani hemodialisa diantaranya penyakit ginjal ESRD (End Stage Renal Disease) 84\%, gagal ginjal akut ARF (Art Proteins Modulate) 9\%, dan gagal ginjal akut pada gagal ginjal kronis 7\% (IRR, 2014).

Studi pendahuluan yang didapatkan di Rumah sakit Grandmed Lubuk Pakam, Bulan Juni 2017 hingga Juni 2018 menunjukkan bahwa terdapat 18.666 pasien rawat jalan dan sebanyak 427 pasien adalah pasien gagal ginjal kronik dan yang menjalani hemodialisa secara regular sebanyak 108 pasien dan pasien rawat inap sebanyak 65 pasien (Rekam Medik, Juni 2018).

\section{METODE PENELITIAN}

Penelitian ini merupakan praeksperimen dengan rancangan one group pre test-post test design untuk mengetahui apakah ada pengaruh aromaterapi inhalasi terhadap penurunan nilai kecemasan pada pasien gagal ginjal kronik yang menjalani hemodialisa sebelum dan sesudah diberikan aromaterapi inhalasi.

Populasi penelitian ini adalah seluruh pasien gagal ginjal kronik yang menjalani hemodialisa di RS. Grandmed Lubuk Pakam dan peneliti mengambil sampel berjumlah 13 responden sesuai dengan kriteria inklusi penelitian. Teknik sampel yang digunakan yaitu Non Probability Sampling dengan pendektan tehnik Purposive Sampling.

Pengumpulan data dilakukan dengan observasi dan wawancara diukur dengan menggunakan Hamilton Rating Scale for Anxiety (HRS-A) dengan Score (0-56). 
Dari seluruh sampel yang terpilih dilakukan observasi dan wawancara (pre test) terhadap responden 10 menit sebelum dilakukan pemberian aromaterapi inhalasi. Menggunakan selembar kertas tissue untuk diteteskan essensial oil Lavender 0,6 ml, ajarkan pasien untuk bernafas rileks selama 5 menit. Setelah rileks kemudian selipkan di kerah blouse atau kemeja pasien dengan mengintruksikan relaksasi penghirupan aromaterapi inhalasi selama 30 menit. Setelah pemberian aromaterapi selama 30 menit, observasi kembali terhadap penurunan nilai kecemasan setelah pemberian aromaterapi inhalasi.

Data hasil observasi dan wawancara yang telah terkumpul selama penelitian ditabulasi dengan menggunakan perangkat/program komputerisasi. Data tersebut dianalisis denganmenggunakan uji t-test yaitu sample paired t-test untuk mengetahui adanya perbedaan nilai kecemasan sebelum dan sesudah diberikan aromaterapi inhalasi dengan tingkat kepercayaan $95 \%(a=0,05)$.

\section{HASIL PENELITIAN}

Didapatkan rerata nilai kecemasan sebelum dilakukan pemberian aromaterapi inhalasi pada pasien gagal ginjal kronik yaitu dengan nilai rata-rata 37.15 dengan standart deviasi 5.942, dan nilai rata-rata sesudah dilakukan pemberian aromaterapi inhalasi 19.08 dengan standart deviasi 2.875 .

Perbedaan rerata nilai kecemasan sebelum dan sesudah dilakukan pemberian aromaterapi inhalasi pada pasien gagal ginjal kronik yaitu dengan nilai rata-rata 28.115 dengan standart deviasi 4.4085. menunjukkan bahwa perbedaan nilai rata-rata antara pengukuran sebelum dan sesudah 18.000 dengan standart deviasi 4.163. Berdasarkan hasil Uji statistik diperoleh nilai $p=0,001$ dimana nilai $p$ lebih kecil dari nilai $a=0,05$ maka dapat disimpulkan hipotesis diterima yaitu ada pengaruh aromaterapi inhalasi terhadap penurunan nilai kecemasan pada pasien gagal ginjal kronik yang menjalani hemodialisa di Rumah Sakit Grandmed Lubuk Pakam tahun 2018.

\section{PEMBAHASAN}

Berdasarkan hasil penelitian yang dilakukan di RS Grandmed Tahun 2019 sebelum diberikan aromaterapi inhalasi dengan nilai rata-rata 37.15 dengan standard deviasi 5.942. Hasil penelitian ini diolah secara statistik dengan sistem komputerisasi. Aromaterapi inhlasi yang merupakan aromaterapi eksternal yang dilakukan tanpa sentuhan meliputi metode inhalasi langsung dan tidak langsung.

Hal ini mungkin terjadi karena, pada saat menghirup aromaterapi inhalasi saat senyawa aroma lavender dihirup, senyawa tersebut dengan cepat berinteraksi dengan sistem saraf pusat dan langsung merangsang saraf pada sistem olfactory, dan meningkatkan konsentrasi monoamine di sistem saraf pusat yang dapat merilekskan sstem saraf untuk mengurang kecemasan yang ada pada pasien.

Berdasarkan hasil penelitian yang dilakukan di RS Grandmed Tahun 2018 sesudah diberikan aromaterapi inhalasi dengan nilai rata-rata 19.08 dengan standard deviasi 2.875 hasil penelitian yang diolah secara statistik dengan system komputerisasi dan data didapatkan dari hasil observasi wawancara yang didapatkan hasil penurunan rerata nilai kecemasan 
sesudah dilakukan pemberian aromaterapi inhalasi dengan panduan penilaian kecemasan yang terlampir pada bab sebelumnya.

Kemungkinan dapat terjadi karena penggunaan aroma lavender dengan inhalasi dan penggunaan kertas tissue lebih memudahkan penyebaran aroma untuk merelaksasikan tubuh dan sistem saraf yang terkat dengan rasa cemas.

Berdasarkan hasil penelitian yang dilakukan di RS Grandmed Tahun 2018 diperoleh dari uji statistik t-test yang didasarkan pada tingkat kepercayaan $95 \%(a=0,05)$ didapat hasil Sig. (2tailed) atau $\rho$ value $=0.001$. Hal berarti bahwa nilai $p<a(0,05)$ yang berarti bahwa hipotesa pada penelitian ini diterima yaitu ada pengaruh pemberian aromaterapi inhalasi terhadap penurunan nilai kecemasan pada pasien gagal ginjal kronik yang menjalani hemodialisa di RS Grandmed Tahun 2018.

Adapun jenis aromaterapi inhalasi yang digunakan adalah aromaterapi lavender yaitu jenis aromaterapi yang dapat merilekskan dan menurunkan kecemasan pada pasien gagal ginjal kronik yang menjalani hemodialisa. Aromaterapi lavender ini memberikan manfaat untuk relaksasi, kecemasan, perbaikan mood, dan peningkatan kekuatan gelombang alpha sangat bermanfaat dalam kondisi relaks mendorong aliran energy kreativitas dan perasaan segar dan sehat. Kondisi gelombang alpha ideal untuk perenungan, memecahkan masalah, dan visualisasi, bertindak sebagai gerbang kreativitas seseorang. Minyak Lavender salah satu aromaterapi yang terkenal memilki efek menenangkan (Argi, 2013).

Aromaterapi Lavender memilki banyak potensi karena terdiri atas beberapa kandungan. Menurut penelitian, dalam $100 \mathrm{gr}$ bunga
Lavender tersusun atas beberapa kandungan, seperti: minyak essensial (1-3\%), alpha-phine $(0,22 \%)$, limonene $(1,06 \%)$, linalool $(26,12 \%)$, borneol $(1,21 \%)$, linalyl asetate $(26,32 \%)$, geranyl asetate $(2,14 \%)$. Berdasarkan data di atas, dapat disimpulkan bahwa kandungan utama dari bunga lavender adalah linalyl asetate dan linalool (Muchtaridi, 2015).

Hasil penelitian di atas menunjukkan adanya perbedaan terhadap penurunan nilai kecemasan. Hal ini dikarenakan setelah responden menghirup aromaterapi inhalasi dari bunga Lavender maka molekul serta partikel Lavender akan masuk melalui saluran nafas (hidung) selanjutnya kan diteruskan oleh reseptor saraf diterima sebagai signal yang baik dan kemudian dipresentasikan sebagai aroma yang menyenangkan dan ditahap akhir rangsangan bau tersebut akan masuk dan mempengaruhi sistem limbik sebagai pusat emosi seseorang sehingga perasaan menjadi lebih rileks. Dengan perasaan tenang akan membuat pasien dapat berfikir secara tenang untuk dapat mengatasi stressor, sehingga akan tercipta koping yang adaptif. Koping yang adaptif membuat pasien dapat menerima kondisinya dengan baik dan tidak mengalami kecemasan yang semakin meningkat.

\section{KESIMPULAN}

Hasil penelitian membuktikan bahwa ada perbedaan nilai rata-rata antara pengukuran sebelum dan sesudah 18.000 dengan standart deviasi 4.163. Hasil Uji statistik didapatkan nilai $p=0,001$ dimana nilai $p$ lebih kecil dari nilai $a=0,05$ maka dapat disimpulkan bahwa hipotesis pada penelitian ini diterima yaitu ada pengaruh aromaterapi inhalasi 
terhadap penurunan nilai kecemasan pada pasien gagal ginjal kronik yang menjalani hemodialisa di RS Grandmed Lubuk Pakam tahun 2018.

Aromaterapi inhalasi dapat digunakan sebagai salah satu terapi alternative dan terapi komplementer untuk mengatasi kecemasan yang dialami pasien gagal ginjal kronik yang menjalani hemodialisa serta meminimalkan efek samping terapi farmakologi. Selain itu disarankan kepada pasien gagal ginjal kronik yang menjalani hemodialisa agar dapat menerapkannya sendiri saat mengalami kecemasan selama menjalani hemodialisa karena aromaterapi inhalasi ini sangat mudah diaplikasikan dan sangat bermanfaat.

\section{DAFTAR PUSTAKA}

Argi, 2013. Aroma Terapi Herbal. Jakarta: Salemba Medika

Grosset \& Giddes, 2010. Terapi sehat dengan pengobatan alternative. Bandung: Pustaka Hidayah.

Hidayati, 2011. Terapi Alternatif. Yogyakarta: Pradipta Publishing.

Hidayat. 2013. Metode Penelitian Keperawatan dan Teknik Analisa Data. Jakarta: Salemba Medika.

Jaelani, 2009. Aroma Terapi. Jakarta. Pustaka Populer Obor.

Moelyono, Dr. 2015. Aroma Terapi Tinjauan Aspek Kimia Medisinal. Yogyakarta: Graha IImu.

Muchtaridi, 2015. Aspek Kimia Aroma terapi. Bandung: Pustaka Hidayah

Notoatmodjo, S. 2012. Metode Penelitian Kesehatan. Jakarta: Rineka Cipta.
Prasetyono, 2013. Kiat mengatasi cemas dan depresi. Bandung: Tugu Publisher.

Report of Indonesian Renal Registry (IRR).2014: m.indonesianrenalreistry.org

Rustina, 2012. Hubungan antara lama menjalani hemodialisa dengan depresi pada pasien dengan sakit ginjal kronik.portalgaruda.org

Saryono \& Anggraeni, M. 2013. Metodelogi penelitian kualitatif dan kuantitatif dalam bidang kesehatan. Yogyakarta: Nuha Medika

Sastroasmoro, Sudigdo. 2013. Dasardasar metodologi Penelitian klinis. Edisi 3 Jakarta: CV. Sagung seto

Setiati, Siti, 2013. Ilmu Penyakit Dalam. Jakarta Pusat: Interna Publishing

Solehati, Tetti. 2015. Konsep dan Aplikasi Relaksasi Dalam Keperawatan Maternitas. Bandung: PT. Refika Aditama

Sugiyono, 2012. Metodologi Penelitian Pendidikan. Bandung: Alfabeta

Wibowo, Yudhi. 2014. Keperawatan Medikal bedah Manajemen klinis untuk hasil yang diharapkan. Indonesia: Salemba Medika

Widyono, 2015. Aromaterapi Inhalasi sebagai Evidence Based Nursing pada pasien GGK yang menjalani hemodialisa untuk mengurangi kecemasan. Indonesian Resource Journal

Witarsa, 2014. Pengaruh Aromaterapi Inhalasi Terhadap penurunan tingkat kecemasan pasien gagal ginjal kronik yangmenjalani hemodialisa di RSUD Denpasar.Portalgaruda.org 